\title{
Holy Toledo: Muslim-Christian Relations and Catholic Nationalism in Vicente Blasco Ibáñez's The Shadow of the Cathedral
}

\section{Frederick Hale}

\begin{abstract}
Although the eminent Spanish novelist and anticlericalist Vicente Blasco Ibáñez (1867-1928) received little scholarly attention outside his homeland for several decades, he gained significantly greater international notice in the latter half of the twentieth century. His novel of 1903, La Catedral, published in both the United Kingdom and the United States of America six years later as The Shadow of the Cathedral, is a scathing indictment of the conservative Roman Catholic religious establishment in Spain. Blasco Ibáñez faulted its intolerant monopoly on national spiritual life for much of the country's cultural, political, and economic backwardness. Relying heavily on the subsequently discredited nineteenth-century belief that Andalusian Spain had been a model of religious toleration under Islamic hegemony for many generations following the Moorish invasion in the eight century and that this had fostered a golden era of cultural flourishing, he argued for the dismantling of Catholic privilege in favour of secularism, toleration, and pluralistic religious freedom to spur the country out of its stagnancy. This article explores both the construction and recent dismantling of the myth of religious harmony in Moorish Spain and how that perception of the Middle Ages is used rhetorically in The Shadow of the Cathedral.
\end{abstract}

Keywords: Vicente Blasco Ibañez. La Catedral, The Shadow of the Cathedral, Spanish Catholicism, Spanish Realist literature, Spanish republicanism, literary anticlericalism, Raymond F. Hale, Muslim-Christian relations 


\section{Introduction}

The often vexed history of relations between Christians and Muslims has continued to engage many scholars in recent years, not least owing to its currency in a world bedevilled by violent clashes between adherents of these two religions. Since the nineteenth century, there have been numerous quests to uncover times and situations in which not only they but also Jews lived harmoniously with each other, co-existing in society without the deadly hostility which has nearly inured sensitivities in our day.

In the constructed world of imaginative literature, perhaps in few places is this theme more prominent than in the esteemed Spanish novelist Vicente Blasco Ibáñez's work of 1903, La Catedral, which was translated into English and published as The Shadow of the Cathedral. There the protagonist, a relatively young but physically broken Spanish revolutionary and anarchist, attributes to the linking of national fervour and exclusivist Catholicism the woeful downward spiral of Spanish society during the past few centuries and points to medieval Spain's Moorish period as a far more beneficent and fruitful era. According to his provocative reconstruction of history, the Siglo del Oro, or 'golden age' following the Reconquista (the centuries-long royal Catholic reclamation of Spain from Islamic domination), despite its seeming glory, actually carried the germ of the nation's eventual decline. In his eyes, it was a time when intolerance and an enforcement of religious unity through the expulsion of Moors and Jews alike, the launching of the Spanish Inquisition, and other utterly illiberal institutions and practices replaced a preceding era when toleration, education, the arts, and other flowers had blossomed century after century in the multicultural national garden. This myth of convivencia, or harmonious co-existence, was not created by Blasco Ibáñez, but he made it the keystone of his argument in this noteworthy novel.

Critical commentary, however, has largely overlooked both this pivotal motif and its untenability. In such works as Day and Knowlton's $V$. Blasco Ibáñez, the matter is not even mentioned, notwithstanding its crucial significance to the alternative view of Spanish history which Blasco Ibáñez offered as the spearhead of his case against the national Catholic monolith (Day \& Knowlton 1972). In the present article, I shall redress this neglect by first tracing the genesis of the myth of convivencia and its discrediting in recent decades, then exploring how the myth is used rhetorically in The Shadow of the Cathedral. 


\section{The Rise and Fall of the Convivencia Myth}

The precise roots of the convivencia myth are perhaps impossible to ascertain. As Cohen has argued, it is intimately related to assertions which late medieval Jews made about having enjoyed higher levels of acceptance in Islamic than in Christian-dominated societies in Europe, especially after the Ottoman Empire admitted many of the Jews who had been expelled from post-Reconquista Spain in the 1490s (Cohen 1994: 3). This view apparently came to be accepted as historically factual. With regard to the tripartite religious landscape on the Iberian Peninsula during the centuries of Moorish domination, the popularisation of the myth before 1900 has been attributed in part to Heinrich Graetz, arguably the nineteenth century's foremost historian of Judaism. He depicted an urban Iberia in which Jews thrived in one area of life after another; indeed, Spain became 'nach vielen Seiten hin Mittelpunkt der Juden'. Córdoba served as his example. Graetz described how that city had approximately a thousand prosperous Jewish families, 'die an Prachtliebe mit den Arabern wetteifern konnten'. Far from being a cowed subgroup who maintained a low profile in ghettoes to ensure their survival,

Sie kleiderten sich in Seide, trugen kostbare Turbane und fuhren in Prachtwagen. Sie ritten hoch zu Roß mit wallenden Federbüschen und eigneten sich ein ritterliches Wesen mit eine Grandezza an, die sie vor den Juden anderer Länder vorteilhaft auszeichnete (Graetz 1888: 359).

Not only their sartorial splendour but also their sense of social equality or even superiority blossomed under Moorish domination in the pages of Graetz's history:

Wenn sie die Ritterlichkeit mit den andalusischen Arabern teilten, so übertrafen sie dieselben an Ehrenhaftigkeit und Edelsinn, die sie immer noch bewahrten, als die Araber bereits entartet wurden. Gleich ihren Nachbarn hatten sie ein stolzes Selbsbewußtsein der eigenen Persönlichkeit, das sich in einer langen Namenreihe aussprach; aber dies Selbstgefühl ruhte auf tief sittlichtem Grunde; sie hatten Ahnenstoll (Graetz 1888: 363).

Intellectually, they soared to heights that made them the envy of their coreligionists elsewhere, who came to regard them 'als Wesen höherer Art'. 
Indeed, in Graetz's interpretation, cities like Córdoba, Lucena, and Granada gained a status in the international Jewish mentality previously occupied by Tiberias, Sura, and Pumbedita (Graetz 1888: 364).

The 'myth of an interfaith utopia' performed a timely rhetorical function in the nineteenth century as constitutional democracy espousing principles of equality regardless of such factors as religious identity made uneven and often disappointingly slow progress in several parts of Europe. Jewish demands for full social acceptance and equal legal standing were frustrated in some countries. If even in medieval, Moorish Spain we were entirely integrated to the point where a Jewish intellectual like Maimonides was esteemed by Islamic counterparts, their argument ran, why is that not the case in ostensibly liberal, modern Europe? (Cohen 1994: 3-4). As Cohen has maintained, the postulate of medieval equality in Andalusian Spain remained 'largely unchallenged' until the twentieth century, when it was appropriated by Arabs in their rhetorical struggle against Zionism. They adduced the Moorish world of approximately a millennium earlier as an example of how Jews could thrive under tolerant, benevolent Islamic hegemony, an argument which Zionists felt compelled to counter (Cohen 1994: 6).

In both Jewish and Christian scholarship, the myth of convivencia was essentially laid to rest in the late twentieth and early twenty-first centuries. At the end of his detailed study Cohen concluded,

In Islam, Jews and Christians, though protected as dhimmis, were considered infidels and suffered humiliation and contemptuous treatment from the dominant group. This was in keeping with their religious inferiority and lowly rank in the hierarchy of Muslim society (Cohen 1994: 195).

Building on Cohen's ground-breaking work from the 1990s, David Nirenberg offered a more balanced view of relations between Muslims, Jews, and Christians in pluralistic medieval societies of southern Europe. At times their proximity seems to have fostered toleration and co-operation, he allowed, but such was by no means always the case. His own work highlighted 'how Muslim, Jewish, and Christian neighbors loved, tolerated, massacred, and expelled each other-all in the name of God', not least in Moorish Spain (Nirenberg 2014: 3). He dismissed the assumption of 'the more naively progressive strands of modernity' that among medieval Muslims increased 
knowledge of Christianity and Judaism led to greater appreciation of those religions and, accordingly, more acceptance of their adherents. Instead, Nirenberg contended, such knowledge 'was (with very few exceptions) not oriented toward the understanding and accommodation of religious difference in heterogeneous societies. Rather, it was used to buttress the structures of one's faith against the claims of others' (Nirenberg 2014: 32).

From a Christian perspective, Darío Fernández-Morera administered the coup de grâce to the little that remained of what he derisively termed 'the myth of the Andalusian paradise' (Fernández-Morera 2006; Fernández-Morera 2016). His purpose, he declared, was 'to demystify Islamic Spain by questioning the widespread belief that it was a wonderful place of tolerance and convivencia of three cultures under the benevolent supervision of enlightened Muslim rulers'. This was necessary, Fernández-Morera declared, because the nineteenth century romantic vision of Islamic Spain has morphed into today's 'mainstream' academic and popular writings that celebrate 'alAndalus' for its 'multiculturalism', 'unity of Muslims, Christians, and Jews', 'diversity', and 'pluralism', regardless of how close such emphasis is to the facts'. He lamented that notwithstanding all the evidence to the contrary, 'some scholars of the Spanish Middle Ages have even openly declared an interest' in advocating the emulation of the supposedly tranquil and tolerant conditions they believed then existed. Fernández-Morera granted that his frank reassessment 'may seem less than savory to modern readers' (FernándezMorera 2016: 2).

This Harvard-educated scholar then proceeded to dismantle the foundation of the myth stone by stone, beginning with what he believed was the credulous conviction that the 'Muslim takeover was accomplished largely through "peaceful pacts" and what he decried as a refusal to identify it a 'conquest', preferring the innocuous label 'migratory wave'. In fact, Fernández-Morera maintained, the 'pacts' which the 'Muslim conquerors' extended were accepted only under great duress by 'subaltern' Iberians who did so rather than 'face the consequences of resisting ... the threat of brute force' (Fernández-Morera 2016: 2). After the rapid imposition of Moorish hegemony, he found, there was extensive and sustained 'religious and therefore cultural repression in all areas of life and the marginalization of certain groupsall this in the service of social control by autocratic rulers and a class of religious authorities' (Fernández-Morera 2016: 2-3). That under such a reign urban Muslim, Christian, and Jewish communities existed in close proximity 


\section{Frederick Hale}

Fernández-Morera did not deny. He believed, however, that they 'dwelled more often than not in their own neighborhoods' but conceded that there was a considerable degree of contact in many areas of life, including marriage. Nevertheless, the overarching reality was that 'even when individual Muslims, Jews, and Christians cooperated with one another out of convenience, necessity, mutual sympathy, or love, these three groups and their own numerous subgroups engaged for centuries in struggles for power and cultural survival, manifested in often subtle ways that should not be glossed over for the sake of modern ideals of tolerance, diversity, and convivencia' (FernándezMorera 2016: 3). Fernández-Morera judged it to be historiographically inexcusable to regard the Umayyad Caliphate which controlled much of Iberia (along with most of North Africa and the Middle East for approximatley three centuries after the conquest in the eight century) 'as an inspiring example of tolerance and convivencia of the three faiths (Islam, Judaism, and Christianity)'. The empirical reality was vastly different: 'The celebrated Umayyads actually elevated religious and political persecutions, inquisitions, beheadings, impalings, and crucifixions to heights unequaled by any other set of rulers before or after in Spain' (Fernández-Morera 2016: 119-120).

\section{Vicente Blasco Ibáñez as Critic of the Nationalist Catholic Establishment}

As a journalist, novelist, and politician, Blasco Ibáñez strove through social criticism to prod Spain out of its conservative mould which for centuries had shaped the country in what he perceived as a stultifying alliance of antiquated nationalism and Catholicism. An ardent foe not only of the ecclesiastical structure which he believed had held the Spanish people in a cultural and intellectual straitjacket since the waning of the Siglo del Oro but also of a bouquet of Christian doctrines which he believed had been discredited by nineteenth-century scientific and other advances, he foregrounded anticlericalism in many of his fictional and nonfictional works. Virtually no holy cows in the shed of religion were off limits to his satirical estoque. At the same time Blasco Ibáñez, like many of his contemporaries, believed the monarchy was an outdated institution, and at times he espoused not only republicanism but also non-Marxist socialism, and he flirted with anarchism without becoming a fully-fledged devotee of it. All of these Leitmotive in his 
works come to the fore in The Shadow of the Cathedral. By the first decade of the twentieth century Blasco Ibáñez had gained international renown, and within Spain he was sometimes heralded as only second to the famed Benito Pérez Galdós as a man of contemporary letters. Many of his books were soon translated into English and other languages, including La Catedral, which was issued in London and New York under the title The Shadow of the Cathedral in 1909. To be sure, in Spain his radicalism also emboldened his detractors, and in the English-speaking world critical analysis of his works lagged far behind their popularity. In the United States of America, for example, William Dean Howells, one of the foremost literary critics of the early twentieth century, sought to call greater attention to Blasco Ibáñez as early as 1915 (Howells 1915), and in the early 1930s Raymond F. Hale, a specialist in modern Spanish literature, undertook analysis of key themes in his novels (Hale 1931; Hale 1933). However, not until the second half of the century could one speak of a noteworthy growth of critical studies of this key Spanish writer. (See especially Smith 1976a.) Many decades passed before British specialists in Spanish literature turned their attention to him.

\section{The Shadow of the Cathedral}

As Hale and other critics noted in the nascent period of scholarship, The Shadow of the Cathedral marked a new departure in Blasco Ibáñez's literary output. Prior to 1903, he had concentrated on creating realistic images of life in Valencia. Beginning with The Shadow of the Cathedral, however, his political agenda came to the fore (Hale 1933: 342). The plot is economical, focusing on the return of a prodigal son of Toledo, Gabriel Luna, to his home after many years of international revolutionary activity and frequent imprisonment stemming from his anarchic and socialistic challenges to the status quo in Spain and abroad. In the last few decades of the nineteenth century, he has lived in inter alia France, England, and the United States of America, drunk deeply at the wells of radical politics and progressive intellectualism, and lost the Catholic faith of his youth after beginning theological training for the priesthood. Indigent, and his health broken by respiratory and other ailments, he finds accommodation at the home of his brother, a layman who is employed at the cathedral. He and many other staff members occupy habitaciones, or modest living quarters, in the claustro, or 
cloister, on the premises. These underpaid servants of the church are a community unto themselves, many of them members of families who have performed similar ecclesiastical functions generation after generation. Nearly all of the narrative unfolds in or within a stone's throw of the cathedral. Its higher-ranking clergy are portrayed as insincere parasites with far less interest in promoting the spiritual welfare of the archdiocese than of feathering their nests and preserving the stability of the national religious heritage, even though the patrimony of intense and widespread popular piety has faded considerably, and the flow of revenues has diminished to a trickle. The famous Gothic cathedral as the venue of the plot is an obvious use of synecdoche; it symbolises the national religious establishment generally.

As a free spirit and misfit in this stifling environment, the erstwhile believer Luna maintains a low profile for many months, occasionally performing menial tasks for the cathedral staff while engaging in discussions with the other residents in which he seeks to enlighten them to the postorthodox knowledge he has acquired about history, natural science, politics and economics from a quasi-Marxist perspective. At times his remarks are direct assaults on Catholic doctrine. The general backwardness of Spanish society and the ignorance of its common people is highlighted in Luna's extended comments to these cloistered folk. Increasingly, they seem to adopt his views. On occasion, however, Luna imperils his personal security by engaging in dialogues with rigidly conservative members of the clergy, to whom his opinions are heretical threats to their status. Eventually several men whom he has convinced are being exploited by the wealthy church decide to take matters into their own hands by stealing gems from the cathedral while Luna is serving as a night watchman. He opposes their action, seeing it as a misdirected attempt at self-enrichment rather than part of a genuine revolution with the possibility of alleviating the poverty of the people generally. Luna is severely injured while attempting to resist their crime and dies very shortly thereafter.

\section{Debating the Myths of Medieval Moorish Toleration and the Siglo del Oro}

In the sixth chapter of The Shadow of the Cathedral Luna and a senior cathedral priest, Don Antolin, who voices the national Catholic legacy as a force 
undergirding the past glory of Spain, exchange conflicting views of when and why the nation was in its glory. To the conservative cleric, this was clearly in the two centuries following the completion of the Reconquista by Catholic monarchs who in the fifteenth century drove out the last remnants of Moorish hegemony, expelled or forced the conversion of its Jewish residents, and unified Spain under the banner of the church. He argues that in the sixteenth and seventeenth centuries the country consequently attained the apogee of its wealth, international influence, and empire.

Luna, however, as an ardent foe of the Catholic establishment and critical of its intolerance of other religions, disagrees stridently. Their verbal duel lucidly illustrates Blasco Ibáñez's rhetorical assault on the received tradition of Catholic nationalism and his reliance on the myth of the convivencia as a counterargument. Defying accepted verities about Spanish history, particularly as incorporated in and advocated by the national religious leadership, Luna asserts:

Those centuries that you describe as those of greatness and well-being were really the worst in our history; they were the cause of Spanish decadence, and the beginning of all our ills.

Don Antolin rejects this categorically and proudly boasts about the achievements of the Siglo del Oro while faulting nineteenth-century trends for what he tacitly concedes are the country's current woes. 'How can you say that those times were evil, and that the fault is theirs of what is happening to us now?' he asks. 'The true culprit is liberalism, the unbelief of the age, which has let the devil loose in our house'. It is post-Catholic thought, this prelate insists, that has cost Spain its erstwhile domestic glory and international esteem. 'We have lost our islands, we count for nothing among the other countries', Don Antolin laments. His answer to the crisis is a resurrection of past forces which he believes ushered in its hitherto high status. 'We are nothing without the throne and the altar, and the proof of this is everything that has happened to us since we had revolutions', he tells Luna bluntly. The core of his case is taken from the history of the Reconquista. 'Go into the choir, and you will see on the lower stalls all the battles that those religious kings gained over the Moors with the help of God', Don Antolin urges. 'They conquered Granada and drove out the infidels who had held it seven centuries in barbarism'. The overthrow of Islamic hegemony not only revealed what an 
alliance of Catholic faith and Spanish nationalism could achieve but also ushered in an era when the kingdom was one of the world's greatest powers. Don Antolin continues his efforts to overwhelm the sickly Luna with a chronicle of Spanish power after the reunification of much of Spain under Ferdinand and Isabella. Only Spaniards could discover America, he declares, ignoring the fact that Christopher Columbus was a Genovese. Subsequently, Charles V (whom he does not mention was actually a Habsburg from Ghent but calls by his explicitly Spanish name 'Don Carlos') brought Spain to the apex of its political and military power in Europe while extending its global empire to the point that the sun never set on it. 'We want the glorious past, the brilliant times of the Catholic kings, of Don Carlos and the two Philips, and it is on them that we fix our eyes when we talk of Spain returning to her good old times' (Blasco Ibáñez 1909: 177-180).

Entirely unswayed, Luna proceeds to kick the epistemological supports out from beneath Don Antolin's historical argument and offer an alternative interpretation of Spanish history. He accuses his conversation partner of merely echoing what he had been taught in school, i.e. apeing the received, national Catholic version of the religio-political past. 'The fault is in the education that is given in this country', he explains. 'All history is a lie, and to know it so misrepresented it would be far better not to know it at all' (Blasco Ibáñez 1909: 180).

In a lengthy argument, Luna juxtaposes the last four centuries of the Catholic religious monolith, which he believes has exercised a stultifying influence on Spain's development (despite part of it being generally called a 'golden age'), with the Middle Ages as the real era of Spanish greatness, a time that 'held great hopes' which, alas, 'have vanished since the consolidation of national unity'.

Our Middle Ages produced a cultivated, industrious and civilised people like none other in the world; they had in them the materials for the building of a great nation; but foreign architects came in who hastily ran up this edifice; those first few years of existence that astound you with the splendour of novelty, and among whose ruins we are still groping.

Putting flesh of details on the bones of his general assertion while simultaneously slaughtering another sacred cow in the received tradition, Luna 
insists that in the eighth century 'the regeneration of Spain did not come from the north with the hordes of barbarians, but from the south with the invading Arabs'. He immediately tempers his use of 'invading', however, stating that

the Spain of those days gratefully welcomed the people from Africa and submitted without resistance. A squadron of Arab horsemen was sufficient to make a Spanish town open its gates. It was a civilising expedition more than a conquest, and a continual current of immigration was established over the Straits (Blasco Ibáñez 1909: 180-181).

What his sources are for his post-orthodox challenges to the conventional interpretation, he does not reveal; his version is merely posited as a sorely needed corrective.

Thus lightly armed for rhetorical battle, Luna constructs his case hyperbolically by describing the cultural florescence of Moorish Spain in ways which underscore its superiority to the stagnation of recent centuries. The spiritual and cultural pluralism of Spain from the eighth century onward sprang in part from 'the religious enthusiasm of the Prophet', whose belief system incorporated 'all that was best in Judaism and in Byzantine civilisation, carrying along with it also the great Indian traditions, fragments from Persia and much from mysterious China'. Luna finds it entirely plausible that such an amalgam of excellence in this 'youthful civilisation' appealed to Iberians, 'who received the invaders with open arms'. Spain, he asserts, had hitherto been 'the slave of theological kings and warlike bishops'. No wonder, Luna argues, that the Reconquista then took seven centuries to complete (Blasco Ibáñez 1909: 181). Why there had been such a movement to rid the country of its supposedly benevolent and popular Muslim overlords, however, he does not attempt to explain.

Instead, Luna describes medieval Andalusia in glowing terms as a forerunner of modern, international examples of stimulating and beneficent toleration. Not least did multivalent spiritual life thrive in such an environment after the Moors arrived. 'The principle of religious liberty which cements all great nationalities came in with them, and in the conquered towns they accepted the Church of the Christians and the synagogues of the Jews', he professes without qualification. 'The Mosque did not fear the temples it found in the country, it respected them, placing itself among them, without jealousy 
or desire of domination'. In this rainbow nation of religious faiths, cultural life could thrive as never before, and it did so until the completion of the Reconquista. 'From the eighth to the fifteenth century the most elevated and opulent civilisation of the Middle Ages in Europe was formed and flourished'. Luna strongly implies that the relative backwardness of most other European countries could be attributed at least in part to their policies of linking Christianity to the state and either forbidding or placing at a disadvantage all other faiths, whereas under Moorish rule much of Spain was an almost Edenic society foreshadowing Jeffersonian America with is foundational separation of church and state and its constitutional provision of pluralistic religious freedom: 'While the people of the north were decimating each other in religious wars, and living in tribal barbarity, the population of Spain rose to thirty millions, gathering to herself all races and all beliefs in infinite variety, like the modern American people'. Indeed, in Luna's historical imagination Moorish Andalusia was a kind of proto-melting pot where

Christians and Mussulmen, pure Arabs, Syrians, Egyptians, Jews of Spanish extraction, and Jews from the East all lived peaceably together, hence the various crossings and mixtures of Muzarabes, Mudejares, Muladies and Hebrews.

They all added their distinctive flavours to the delectable stew:

In this prolific amalgamation of peoples and races all the habits, ideas, and discoveries known up to then in the world met; all the arts, sciences, industries, inventions and culture of the old civilisations budded out into fresh discoveries of creative energy.

Luna showers Don Antolin with a stream of examples drawn from many walks of life to undergird his point:

Silk, cotton, coffee, oranges, lemons, pomegranates, sugar, came with them from the East, as also carpets, silk tissues, gauzes, damascene work and gunpowder. With them also came the decimal numeration, algebra, alchemy, chemistry, medicine, cosmology and rhymed poetry.

He pointedly emphasises that the Hellenistic philosophical legacy which had provided a significant component of the intellectual underpinnings of Catholic 
theology owed its transmission to early medieval Europe partly to nonChristians:

The Greek philosophers, who were nearly vanishing into oblivion, saved themselves by following the footsteps of the Arab conquerors. Aristotle reigned in the university of Cordoba.

In yet another juxtaposition which places Catholic-dominated Europe in an unfavourable light,

While in the barbarous Europe of the Franks, the Anglo-Normans, and the Germans, the people lived in hovels, and the kings and barons in rocky castles blackened by the smoke of their fires, devoured by vermin, dressed in coarse serge, and fed like prehistoric man, the Spanish Arabs were raising their fantastic Alcazars, and, with the refinement of ancient Rome, they met at the baths to converse on all literary and scientific questions (Blasco Ibáñez 1909: 181).

In accordance with his belief that such conditions prevailed generally, Luna strikes yet another blow at medieval Catholicism elsewhere while defending Andalusian pluralism:

If any monk from the north felt the hunger of learning, he came to the Arab universities or the Jewish synagogues of Spain, and the kings of Europe thought they would be cured of their infirmities if, by dint of golden bribes, they could procure a Spanish physician (Blasco Ibáñez 1909: 181-183).

Having resided in several other countries, including the United Kingdom, Luna can argue with at least marginal cogency on grounds comparing the cultural state of Spain with that elsewhere. He reasons that the momentous legacy of Moorish-dominated, pluralistic Andalusia provided much of the cultural impetus for the Siglo del Oro after the Reconquista had finally been achieved and Spanish geopolitical power was at its apogee. That period in the sixteenth and seventeenth centuries was nevertheless 'execrable', Luna insists, because it 'turned Spain from the right way, rousing in us religious fanaticism and the ambition of universal empire'. He grants that for 
an unspecified period after approximately 1500 A.D. Spain stood 'two or three centuries ahead of the rest of Europe' and was 'for the world of those days what England is for our own times'. Alas, this immense historical advantage had then been sacrificed on the altar of an intolerant alliance of royalism, nationalism, and Catholicism. 'If we had followed the same policy of religious toleration, of fusion of races, of industrial and agricultural work in preference to military enterprises, where should we not be now?' he asks rhetorically (Blasco Ibáñez 1909: 184).

\section{Conclusion}

If in the sacred spheres of theology 'yesterday's heterodoxy is today's orthodoxy', in the even more malleable world of historiography many of the accepted verities of the past no longer ring true today. Both primary research and critical discourse analysis of what historians have claimed constantly alter our perceptions and interpretations of events, phenomena, and trends that have been etched into the stones of historical writing. This is particularly true with regard to such controversial matters as religious freedom and interfaith relations, not least when ethnic hegemony is linked to questions of spiritual beliefs and practices.

In his zeal to offer an emulable era in Spanish history which could serve as an alternative to what he perceived as the stultifying hand of exclusive Catholic dominance in a unitary state, Vicente Blasco Ibáñez grasped at the convenient legacy of the supposed convivencia and blithely constructed much of his case on it. Given the popularity and hardiness of this long unchallenged myth, his employment of it in The Shadow of the Cathedral continued to bolster his case long after that novel was published in 1903. He died in 1928, several decades before the notion of laudable and symbiotic harmony among Muslims, Christians, and Jews in medieval Spain succumbed to far more critical research than Heinrich Graetz had conducted. The demythologising works by Cohen, Fernádez-Morera, and others in recent years have rendered the once-popular belief in historic convivencia untenable, at least until itpossibly-is restored by currently unforeseen historical scholarship.

Consequently, the value of The Shadow of the Cathedral is now different from what it was for much of the twentieth century. It underscores, inter alia, how religious history can be appropriated, manipulated, and shaped 
for rhetorical purposes. To be sure, not only postmodernist historians who reject conventional empirical historiography have long emphasised that fundamental point. There has long been a consensus in the profession that the writing of history involves selective amnesia, exaggeration, and other forms of misrepresentation, both unintentional and otherwise.

Moreover, a close reading of The Shadow of the Cathedral indicates that Gabriel Luna's view of Spanish history, including that of its Siglo del Oro, is no less simplistic than Don Antolin's. Both men have severely reductive views of Spain's convoluted past and the role of the Catholic Church in it, and each of these Spaniards sets forth his bargain-basement abridgement of that history to serve his rhetorical purpose. Consequently, they do little more than talk past each other. Perhaps unconsciously, Blasco Ibáñez thus cautions readers about how such conversation, or other discourse in which there is only sparse common ground, falls short of being meaningful communication.

Finally, The Shadow of the Cathedral serves as a reminder of the necessity not only of doing meticulous research before adducing historical evidence in arguments, but also of understanding the ideological and other tropes in one's sources of history and taking cum grano salis virtually any historical argument which rests on unsubstantiated assertions.

\section{References}

Blasco Ibañez, V. 1909. The Shadow of the Cathedral. Gillespie, W.A. (trans.). London: Archibald Constable and Co., Ltd.

Bleiberg, G. 1966. Spanish Thought and Letters in the Twentieth Century. Nashville: Vanderbilt University Press.

Callahan, W.J. 2012. The Catholic Church in Spain, 1875-1998. Washington, D.C.: The Catholic University of America Press.

Carr, P. 1980. Modern Spain 1875-1980. Oxford: Oxford University Press.

Cohen, M.R. 1994. Under Crescent and Cross: The Jews in the Middle Ages.

Princeton: Princeton University Press.

Day, A.G. \& E.C. Knowlton 1972. V. Blasco Ibañez. New York: Twayne Publishers, Inc.

Fernández-Morera, D. 2006. The Myth of the Andalusian Paradise. The Intercollegiate Review 41,2: 23 - 31.

Fernández-Morera, D. 2016. The Myth of the Andalusian Paradise: Muslims, 
Christians, and Jews under Islamic Rule in Medieval Spain. Wilmington, Delaware: ISI Books.

Graetz, H. [1882] 1890 - 1909. Volkstümliche Geschichte der Juden. Volume 2. Leipzig: Verlag von Oskar Leiner.

Hale, R. 1933. Ibañez and Spanish Republicanism. Modern Language Journal 17,5: 342 - 348 .

Hale, R.F. 1931. A Critical Review of the Principal Novels of Vicente Blasco Ibáñez. Master of Arts thesis, University of South Dakota.

Howells, W.D. 1915. The Fiction of Blasco Ibañez. Harper's Monthly Magazine 131,786: 957 - 960.

Nirenberg, D. 2014. Neighboring Faiths: Christianity, Islam, and Judaism in the Middle Ages and Today. Chicago: University of Chicago Press.

Payne, S.G. 1984. Spanish Catholicism: An Historical Overview. Madison: University of Wisconsin Press.

Smith, P. 1976a. Vicente Blasco Ibañez: A Critical Survey of the Novels from 1894 to 1909. Doctor of Philosophy thesis, University of California at Berkeley.

Smith, P. 1976b. Vicente Blasco Ibañez: An Annotated Bibliography. London: Grant \& Cutler Ltd.

Frederick Hale North-West University fh243@cam.ac.uk 